\title{
粚
}

\section{Die identifisering van soteriologiese metafore in 1 Petrus}

\author{
F.J. (Fika) Janse van Rensburg \\ Skool vir Bybelwetenskappe en Bybeltale \\ Potchefstroomkampus \\ Noordwes-Universiteit \\ POTCHEFSTROOM \\ E-pos: sbbjjjvr@puk.ac.za
}

\begin{abstract}
Identifying salvific metaphors in 1 Peter

Not many research findings have been published on soteriology in 1 Peter. This article attempts to make a contribution from a specific angle, viz by identifying the salvific metaphors in 1 Peter and the imageries they constitute. After a survey of the state of the art on soteriology in 1 Peter, the relevant methodological issues (pertaining to soteriology, metaphor and the socio-historical ecology of metaphors) are considered. Then an interpretation of the argument of 1 Peter is given. Finally the salvific metaphors in 1 Peter are identified, a tentative interpretation is given, and a matrix of these metaphors is proposed.
\end{abstract}

\section{Opsomming}

Die identifisering van soteriologiese metafore in 1 Petrus

Min gepubliseerde navorsing bestaan oor die soteriologie in 1 Petrus. Hierdie artikel poog om 'n bydrae hiertoe te maak, en wel vanuit 'n spesifieke hoek, naamlik deur die soteriologiese metafore in 1 Petrus te identifiseer, asook die beeldgroepe wat hulle vorm. Ná 'n oorsig oor die stand van navorsing oor soteriologie in 1 Petrus word enkele metodologiese oorwegings aan die orde gestel (oor soteriologie, metafoor, en die sosiohistoriese ekologie van metafore). Vervolgens word 'n interpretasie van die argument in 1 Petrus gegee. Ten slotte word die soteriologiese metafore in 1 Petrus geïdentifiseer, voorlopig geïnterpreteer, en 'n matriks van hierdie metafore word voorgestel. 


\section{Inleiding}

Die soteriologie 1 in 1 Petrus is tot ' $n$ groot mate verwaarloos in bestaande navorsing. Geen monografie wat handel oor die soteriologie in 1 Petrus kon opgespoor word nie - slegs verspreide en geïsoleerde opmerkings in kommentare en in artikels. Die feit dat soteriologiese gegewens in 1 Petrus verwaarloos is, is reeds duidelik uit De Villiers se oorsig van die teologie van 1 Petrus (De Villiers, 1993:157-170). Soteriologie word naamlik nie as 'n aparte tema in hierdie oorsig aan die orde gestel nie. ${ }^{2}$

In die inleiding van sekere 1 Petrus-kommentare word enkele bladsye afgestaan aan 'n oorsigtelike bespreking van soteriologie, byvoorbeeld Michaels (1988:Ixx-Ixxiv). Oor soteriologie in die algemeen maak Martin (1992:141) egter 'n belangrike opmerking: die ontologiese stellings in 1 Petrus word feitlik uitsluitlik deur middel van vergelykings en metafore verwoord.

Daar is dus ' $n$ behoefte aan 'n sistematiese interpretasie van die soteriologiese gegewens in 1 Petrus. Hierdie artikel waarin metaforiese soteriologiese uitsprake in 1 Petrus geïdentifiseer en geïnterpreteer word, is 'n eerste stap in hierdie rigting.

Martin (1992) het waardevolle werk gedoen oor metafore in 1 Petrus. Hy (Martin, 1992:144, 148) beskou twee aspekte van die Diaspora as die kernmetafoor in 1 Petrus. Die eerste is die gedagte dat die Diaspora slegs tydelik was en beëindig is met die terugkeer van die Joodse volk na hulle tuisland (Martin, 1992:150). Die tweede is die gedagte dat die Diaspora gevaar loop om in die nie-Joodse gemeenskap geassimileer te word, en gevolglik dat die Joodse godsdiens vaarwel toegeroep word (Martin, 1992:156).

Martin (1992:160-161) onderskei drie metafoorgroepe in 1 Petrus, wat reeds in die opskrif in 1:1 aangekondig word, naamlik

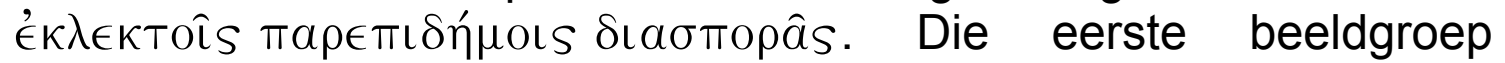

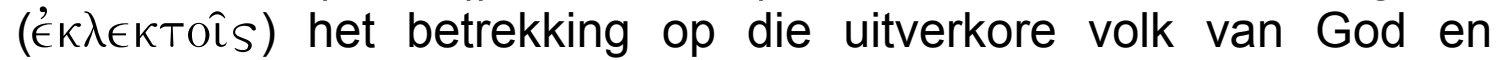
bestaan uit metafore oor die huis van God (1:14-2:10). Die tweede

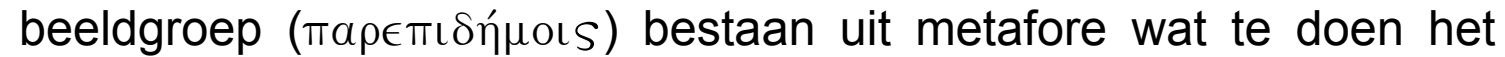
met die uitlandergedagte (2:11-3:12). Die derde beeldgroep

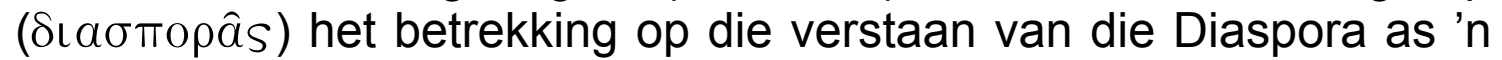

1 Vergelyk 2.1 vir 'n definiëring van "soteriologie".

2 Die verskillende temas wat De Villiers (1993) aan die orde stel, is die volgende: "Suffering, future expectation and joy" (p. 157-161), "Christology" (p. 162-167), "The church" (p. 167-168) en "The Christian way of life" (p. 168-170). 
toestand van lyding (3:13-5:11). Martin (1992:161) beskou al drie hierdie metafoorgroepe as onderling verbind deur die oorkoepelende en beherende metafoor van die Diaspora.

Alhoewel hierdie benadering van Martin meriete het, is die Diasporametafoor myns insiens nie soteriologies van aard nie. Die Diasporametafoor in die brief aan Petrus gaan eerder oor die gevolge van die ontologiese status van die eerste lesers/hoorders, en die fokus is nie gerig op die punt waar oorgegaan word van ' $n$ toestand van verlorewees na 'n toestand van gered-wees nie. 'n Matriks van soteriologiese metafore in Petrus moet dus opgestel word.

\section{Metodologiese oorwegings}

\subsection{Soteriologie}

Soteriologie gaan oor redding, die punt vanwaar oorgegaan word van 'n toestand van verlore wees na 'n toestand van gered wees. Hierdie definisie onderskei soteriologie van moraliteit, ekklesiologie en Christologie. Hierdie verstaan van soteriologie as die punt waar oorgegaan word van 'n toestand van verlorenheid tot 'n toestand van gered wees, funksioneer gevolglik as die rigtinggewende beginsel in die identifikasie en interpretasie van die soteriologiese metafore in 1 Petrus. ${ }^{3}$ Die bedoeling in hierdie artikel is om 'n

3 Marrow (1990:278) onderskei twee verlossingsteorieë: die een teorie word gesien in terme van die loskoopoffer en die ander in terme van die latere voldoeningverdienste. Die loskoopoffer beskou hy as die basis vir die ontwikkeling van die soteriologie tot by die Middeleeue. Dit was eers in die Middeleeue dat begin is om twee verdere kategorieë, naamlik "voldoening" en "verdienste" te gebruik as deel van die siening van die soteriologie (Marrow, 1990:271). Marrow (1990:276) beskou die volgende begrippe as die soteriologiese kernwoordeskat van die

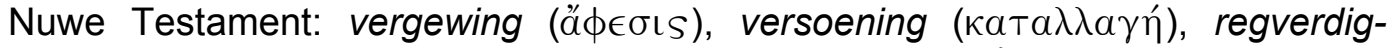

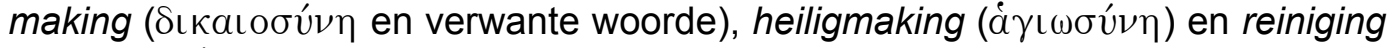

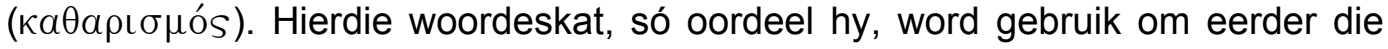
uitwerking van die dood aan die kruis "ter wille van ons" te beskryf, as om die proses waarvolgens dit bewerk word, te beskryf. Hierdie siening bring hom (Marrow, 1990:277) by die gevolgtrekking dat 'n ontleding van die soteriologiese begrippe in die Nuwe Testament moet fokus op die uiteindelike gevolg van die proses en nie op die wyse waarop dit bewerkstellig is nie.

Marrow (1990:278-280) stel verder voor dat vier beginsels gebruik moet word wanneer soteriologese uitsprake in die Nuwe Testament geïnterpreteer word:

(1) Begrippe soos loskoop, verlossing, en offer moet metafories hanteer word.

(2) In gevalle waar die basis in 'n metafoor nie eksplisiet genoem word nie, moet dit so akkuraat as moontlik veronderstel word. (3) Selfs by begrippe waar dit eerder oor die gevolg as oor die proses self gaan, moet hierdie beginsel toegepas word. (4) In gevalle van skynbare oordrewe realisme (byvoorbeeld as na Christus verwys word as lemand wat "n vervloeking vir ons" [Gal. 3:13] geword het) is dit die teks self wat wys dat die fokus op die uitkoms of resultaat van die proses is. 
duidelike onderskeid te handhaaf tussen wat interpreteerders deur die eeue van die soteriologie in 1 Petrus gemaak het en wat die brief self hieroor sê. Die identifikasie en interpretasie van soteriologiese metafore is dus ' $n$ poging om die huidige leser van 1 Petrus in die skoene van die eerste lesers te laat staan. Ook word gepoog om die soteriologie in 1 Petrus in terme van die volgende te beskryf: wat is dit waarvan hulle gered is (die $a b$ quo van hulle redding), en wat was hulle situasie nadat hulle gered is (die ad quem)? ${ }^{4}$

\subsection{Metafoor}

Oor metafore is al baie geskryf. Wanneer 'n mens navorsingsgegewens oor metafore deurwerk, herinner dit jou aan die waarheid van dit wat Aristoteles (Poet., 1459) oor metafore geskryf het:

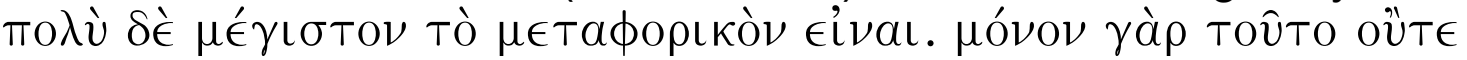

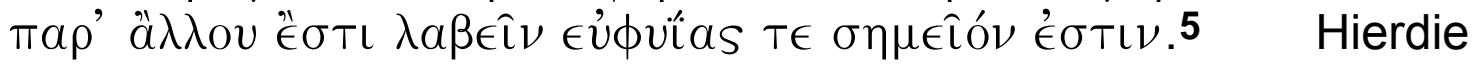
taak word nóg moeiliker wanneer 'n mens metafore moet interpreteer (en nie net skep nie), veral wanneer dit gaan oor metafore van tekste wat 2000 jaar en ouer is. 6 Uit hierdie potensiële chaos is egter tog 'n weg te vind.

\subsection{1 'n Poging om metafoorte definieer}

'n Metafoor is 'n stylfiguur van vergelyking, saam met gelykenis ('n uitgebreide vergelyking) en allegorie ('n uitgebreide metafoor) (Kaiser \& Silva, 1994:93). 7 Vergelyking is een van die kosbaarste

$4 \quad$ Marrow (1990:280) stel dat dit die beste benadering tot die interpretasie van die soteriologiese terminologie in die Nuwe Testament is om met die uitkoms van die proses te begin, dit is met die gevolg van die dood aan die kruis, en om dan daarvandaan terug te werk na die terminologie wat gebruik is om oor die proses te praat. ' $n$ Probleem met sodanige benadering is die risiko van dogmatisering, in plaas daarvan om regtig eksegese te doen.

5 "Die grootste iets wat 'n mens kan vermag, is om metafore te bemeester. Dit is immers die een vermoë wat jy nie van iemand anders kan leer nie. Hierdie vermoë is 'n teken dat iemand regtig geniaal is" (eie vertaling - FJvR).

6 Caird (1980:145) skryf in hierdie verband tereg: "We do not live in the world of the Old or New Testament, we are unacquainted with what to the contemporaries of Isaiah or Paul were familiar, everyday objects or experiences, and it is therefore easy for us to miss the affinities which imposed themselves on the inward eye of the biblical writers."

7 Longman (1987:130) gebruik min of meer dieselfde kategorieë en oordeel dat baie tipes uitbeelding gebaseer is op die beginsel van ooreenkoms. Hy (Longman, 1987:130) beskou 'n metafoor as die mees algemene tipe uitbeelding, met vergelyking as 'n eksplisiete korrelasie daarvan. Longman (1987:130) voeg by: "Indeed it might plausibly be argued that all of the others are really a subtype of the master figure, simile." Van der Watt (2000:6), in aansluiting by Miller 
bronne van kennis, die hoofroete van die bekende na die onbekende (Caird, 1980:144). 'n Metafoor het egter selfs groter krag: dit kan lesers oriënteer en heroriënteer in ooreenstemming met die outeur se perspektief (Mouton, 2002:40).

Nida en Taber (1974:203) se standpunt oor metafore het geblyk oorvereenvoudig te wees. Hulle het naamlik gestel dat 'n metafoor die volgende impliseer: "a figurative expression used instead of another to make an implicit comparison between the items referred to by the two expressions, often based on supplementary components". 8 Die feit dat ' $n$ metafoor 'n beeld is wat gebaseer is op ooreenkoms binne verskil (Longman, 1987:130) word nie verreken nie. 'n Metafoor veronderstel 'n goed gevestigde gebruik van 'n taaluiting (die "letterlike" betekenis daarvan). Op hierdie letterlike betekenis word dan uitgebrei op 'n wyse wat nuut is of eintlik ietwat onlogies is (Thiselton, 1977:94). 'n Metafoor steun dus op 'n letterlike betekenis en tegelykertyd ondergrawe dit die letterlike betekenis en brei dit uit deur middel van transformasie (Mouton, 2002:41).

Vir die doeleindes van hierdie artikel vereenselwig ek my met Thiselton (1977:94-95) se standpunt oor die funksie van 'n metafoor, maar voeg 'n derde funksie by sy twee:

- Eerstens kom 'n spanning tot stand wat daarop gemik is om een of ander reaksie by die hoorder te ontlok.

- Tweedens voorsien die metafoor 'n model of verwysingsraamwerk waarvolgens die hoorder nou núút kyk na die saak waaroor dit gaan. 9

- Die derde funksie van die metafoor wat ek byvoeg, is iets waaraan Gunton (1989:65) sydelings aandag gee, naamlik dat 'n

(1971:127), gee 'n funksionele beskrywing van metafoor: twee leksikale items met uiteenlopende betekenis word aan mekaar verbind op grond van een of ander vorm van vergelyking, met spesifieke semantiese implikasies.

$8 \quad$ Kaiser en Silva $(1996: 93,285)$ neig na dieselfde oorvereenvoudiging. 'n Metafoor is vir hulle ' $n$ stylfiguur waar ' $n$ woord 'n onuitgesproke vergelyking impliseer om te suggereer met watter saak hierdie woord ooreenkom. Die vergelyking is onuitgesproke of bloot geïmpliseer. Die betrokke gedagte word van een element oorgedra na die ander sonder om uitdruklik te stel dat die een element "soos" die ander is.

9 Thiselton (1977:95) stel tereg dat 'n mens nie net van poësie nie, maar ook van 'n metafoor die volgende kan sê: "Its mission is to break through the wall of conventional values that encloses us, to startle us into seeing the world through fresh eyes." 
metafoor gebruik word om iets onder woorde te bring wat nie met alledaagse empiriese terme kan gebeur nie.

Metafore is dus 'n manier om iets wat net op 'n indirekte wyse in alledaagse taal beskryf kan word, onder woorde te bring. Metaforiese betekenis steun op 'n letterlike, algemeen gebruikte basis as kontakpunt (vgl. God as vader, Jesus as redder, die Gees as seël). Wanneer hierdie woord egter binne 'n nuwe veld toegepas word, word nuwe betekenis geskep (Mouton, 2002:41).

\subsubsection{Samestellende dele van 'n metafoor}

In navolging van Van der Watt (2000:18) word die volgende terme gebruik: fokus (die woord wat veroorsaak dat die leser aanvoel dat die betrokke sin nie letterlik verstaan kan word nie) en raam (die res van die sin) waar werkwoorde metafories gebruik word.

Waar die metafoorsin bestaan uit selfstandige naamwoorde, word die terme tenor ('n woord uit die letterlike raam) en vehicle (die figuurlik of metafories gebruikte woord) gebruik.

De Waard (1974:109-110) stel ook 'n bruikbare metode voor vir die ontleding van metafore. Hiervolgens het 'n metafoor drie samestellende dele (De Waard, 1974:109): objek, grond en beeld. ${ }^{10}$

Dit is nodig om te onderskei tussen volledige en verkorte metafore (De Waard, 1974:109). ${ }^{11}$ Volledige metafore vertoon al drie die samestellende dele (objek, grond en beeld); by verkorte metafore is een of twee van die samestellende dele slegs implisiet.12

10 Kaiser en Silva (1996:93-94) onderskei ook hierdie drie saamstellende dele, maar gebruik 'n eie terminologie: (1) die saak wat deur die beeld beskryf word, (2) die beeld van die direkte of geïmpliseerde vergelyking, en (3) die punt van die direkte of geïmpliseerde vergelyking of ooreenkoms. Martin (1992:147) stem met Weinrich (1976:276-341) saam dat 'n metafoor uit basies twee dele bestaan: die beeld-gewer en die beeld-ontvanger.

11 Hierdie onderskeiding vertoon ooreenkomste met Dagut (1971:96-146) se onderskeid tussen "complex" en "simplex" metafore, asook met Miller (1971:128134) se onderskeid tussen oppervlakmetafoor ('n basiese metafoor wat uit sowel die tenor as die vehicle bestaan) en hangende metafoor (die tenor blyk slegs uit die konteks). Miller onderskei verder ook 'n saamgestelde metafoor (wanneer verskeie metafore in 'n breër verband gekoppel is of saam funksioneer).

12 Gewoonlik is die grond implisiet, ander kere is die objek implisiet, en soms word nóg die objek nóg die grond eksplisiet vermeld. In die sin "die tong [objek] is 'n vuur [beeld]" (Jak. 3:6), is die grond implisiet. Hierdie grond sou kon wees: 


\subsubsection{Beeldgroep}

Met beeldgroep word bedoel die volledige en koherente weergawe van objekte, met ooreenstemmende handelinge en verhoudings wat assosiatief en tematies bymekaar hoort (Van der Watt, 2000:18). ${ }^{13}$ 'n Beeldgroep is 'n metafoorsisteem (Caird, 1980:155), dit is 'n groep metafore wat aan mekaar geskakel is deur hulle gemeenskaplike oorsprong binne 'n spesifieke enkele gebied van waarneming, ondervinding of aktiwiteit. Tipies gebeur dit dat sodanige beeldgroep sy eie subtaal ontwikkel. Elke metafoor uit die betrokke beeldgroep roep eintlik om uitbreiding deur middel van die toevoeging van ander metafore uit dié beeldgroep.

\subsubsection{Dooie metafore}

'n Metafoor kan eintlik net as metafoor wérk wanneer daardie metafoor regtig lééf (Thiselton, 1977:95). Die meeste metafore word spoedig dooie metafore. Hulle vries as 't ware (Martin, 1992:141), omdat hulle hulle metaforiese funksie verloor het en nou gesien word as gewoon letterlike taaluitings. $14 \mathrm{Om}$ te bepaal of ' $\mathrm{n}$ metafoor "lewend" of "dood" is, asook om die graad waarin 'n metafoor sy "lewe" verloor het te bepaal, is 'n wesenlike probleem (De Waard, 1974:113). ${ }^{15}$ Een van die redes vir hierdie probleem is die feit dat

"gevaarlik". In die sin "gaan sê vir daardie jakkals [beeld]" (Luk. 13:32), is die implisiete objek "Herodes"; die implisiete grond kan "geslepe" wees.

13 Voorbeelde van sulke beeldgroepe is skaapboerdery, gesinslewe, genesing, handel, die regswêreld, oorlogvoering, die weer, liefde, gesondheid, die natuur, sport, ensovoorts.

14 Mouton (2002:42) wys op 'n belangrike implikasie van die feit dat 'n metafoor kan "doodgaan". Wanneer 'n metafoor gemeengoed geword het en letterlik verstaan word, het die ooreenkoms omvorm tot "identies dieselfde". Die spanning wat eintlik "n metafoor 'n metafoor maak, is dan wég. Hierdie gevaar is juis 'n werklikheid by godsdienstige metafore, want godsdienstige beelde - op grond van tradisie en rite - verander selde en word spoedig as gewone letterlike taal ervaar.

15 De Waard (1974:113) toon oortuigend aan dat die identifisering van dooie metafore uiters belangrik is by Bybelvertaling, aangesien dooie metafore nie as 't ware weer lewend gemaak moet word en 'n foutiewe vertaling sodoende plaasvind nie. Dagut $(1971: 117,139)$ waarsku teen "hipnotisering" met betrekking tot metafore. Dit gebeur, so redeneer hy, wanneer 'n metafoor wat eintlik dood is in die bronteks, vir die verklaarder/vertaler lewend voorkom, omdat dit die eerste keer is dat die verklaarder die betrokke metafoor teëkom (terwyl die eerste lesers dit as "dood" sou ervaar het). By vertaling kan hierdie verskynsel tot gevolg hê dat 'n uitdrukking in die brontaal verkeerdelik as metafoor in die doeltaal weergegee word. 
die interpretasie noodwendig berus op woordeboekinskrywings (wat in baie gevalle twyfelagtig is), én op 'n analise van die diakroniese proses van metafore (wat beperk word deur die beskikbaarheid van toepaslike primêre literêre bronne).

Gepaardgaande hiermee is daar geen presiese grens tussen metafoor en non-metafoor nie. Dit is eerder 'n geval van 'n kontinuum waarop daar onder andere "dooie'" metafore en blote figuurlike taaluitings (soos metonimie en sinekdogee) aangegee word (Thiselton, 1977:95). Die grens tussen dooie metafoor en idioom is dan ook nog vloeibaar (De Waard, 1974:116).

\subsubsection{Die interpretasie en vertaling van metafore}

Die leser moet intuïtief en berekend die ooreenkoms tussen die objek en die beeld by wyse van 'n proses van eliminering vasstel (Longman, 1987:130). Dié proses sal noodwendig lei tot 'n mate van vaagheid - 'n inherente eienskap van metaforiese taal. Thiselton (1977:95) wys tereg daarop dat 'n verklaarder die moeilike taak het om enersyds te verhoed dat die krag van 'n metafoor verlore gaan deurdat die beeld wegvertaal word. Andersyds moet verhoed word dat die leser die beeld glad nie begryp nie. Wanneer 'n metafoor reeds in die tyd van die Nuwe Testament dood is, is dit nie verkeerd om as 't ware die beeld weg te vertaal ter wille van duidelikheid vir die doeltaalleser nie. Wanneer die metafoor egter lewend is, móét die metafoor die lesers laat dink, dikwels omdat daar ' $n$ berekende dubbelduidigheid in die metafoor opgesluit lê. Die metafoor dien immers as model vir iets anders sonder om self duidelik te maak presies in watter opsig dit ' $n$ model is. Wanneer 'n metafoor wegvertaal word of tot 'n vergelyking omvorm word, is hierdie dimensie verlore (Thiselton, 1977:95).16

\subsubsection{Gevolgtrekking oor die aard van 'n metafoor}

'n Metafoor word beskou as twee leksikale items met uiteenlopende betekenisse wat op grond van een of ander vorm van ooreenkoms verbind is. Hierdie verbinding het spesifieke semantiese implikasies

16 De Waard (1974:111) beredeneer oortuigend - nadat hy tereg die stelling maak dat metafore grootliks gebaseer is op supplementêre of konvensionele komponente - dat dit selde gebeur dat 'n doeltaal dieselfde komponente aan 'n woord sal heg. Hy is dus reg dat dit dikwels só is dat die vertaling van metafore op sigself, met die uitsondering van leenmetafore, skynbaar onmoontlik is. 
tot gevolg. 'n Metafoor het die krag om lesers te oriënteer en te heroriënteer in ooreenstemming met die outeur se perspektief. 'n Metafoor veronderstel dus 'n goed gevestigde gebruik van taal (die "letterlike" betekenis) en brei dan hierdie gebruik uit op so 'n manier dat dit as núút en logies ietwat vreemd ervaar word.

\subsection{Die sosiohistoriese ekologie van metafore ${ }^{17}$}

'n Mens kan die krag van begrippe in 'n teks eers begin verstaan wanneer jy vasgestel het wat daardie begrippe beteken het in die tyd toe dit geskryf is (Van Unnik, 1980:203). Dit is derhalwe belangrik om 'n konstruksie te maak van die waarskynlike sosiohistoriese konteks van 1 Petrus om op hierdie wyse die sosiohistoriese ekologie van die soteriologiese metafore te konstrueer. Die metode wat gebruik word vir die konstruksie van die konteks, is die sosiohistoriese benadering, soos uiteengesit in die publikasie van Van Rensburg (2000:564-582). 18

\section{Die argument van 1 Petrus ${ }^{19}$}

Die basiese soteriologiese stelling in 1 Petrus is dat die Vader die

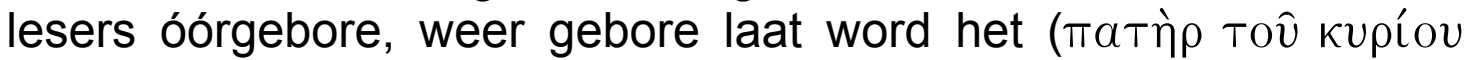

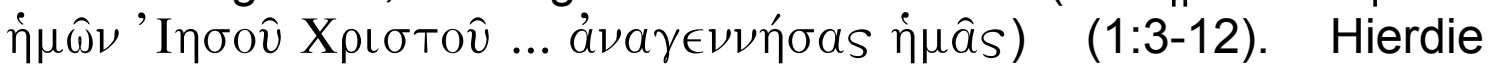
stelling oor hulle weergeboorte funksioneer dan as basis vir vier oproepe:

17 Die sosiohistoriese ekologie van metafore verwys na die totaliteit en onderlinge verweefdheid van die sosiale werklikheid van die antieke Mediterreense wêreld (Van der Watt, 2000:139).

18 Met hierdie benadering skaar ek my by die navorsers van wie Garrett (1992:90), nadat sy die uiterste pole van die sosiohistoriese en sosiowetenskaplike benaderings bespreek het, die volgende sê: "... many have held that the most promising approach is one that continues to employ old methods and questions, but that is also informed by the questions social scientists ask and the models they employ".

19 Die argument van 1 Petrus soos voorgestel deur Van Rensburg (1992:26-41) word as verwysingsraamwerk gebruik in die identifisering van die metafore. 


\section{Die basiese soteriologiese stelling}

1:3-12: Lof kom toe aan God wat julle in Christus weergebore laat word het

\section{Vier opdragte op grond van die weergeboorte deur God}

Opdrag 1: 1:13-25: Vestig julle hoop op die genade, en daarom moet julle lewenswandel heilig wees

Opdrag 2: 2:1-10: 'n Weergeborene se plig ten opsigte van sy persoonlike groei, en sy saamgroei met medegelowiges

Opdrag 3: 2:11-4:19: Gedragsvoorskrifte vir vreemdelinge en bywoners:

2:11-12: Die basiese opdrag vir alle verhoudings

2:13-17: Verhouding met landsowerheid

2:18-25: Verhouding met werkgewers

3:1-7: $\quad$ Verhouding met huweliksmaat

3:8-12: Verhouding met naaste in die algemeen

3:13-4:19: Houding teenoor en reaksie op veronregting Opdrag 4: 5:1-11: Opdragte vir gedrag binne die kerk

\section{Identifisering van die soteriologiese metafore in 1 Petrus}

Met gebruikmaking van die definisie van soteriologie (naamlik dat soteriologie gaan oor die redding, die punt vanwaar oorgegaan word van 'n toestand van verlore wees tot 'n toestand van gered wees, vgl. 2.1 hierbo), en die metodologiese vertrekpunte oor metafoor (vgl. 2.2 hierbo) kan die teks van 1 Petrus met die oog op die identifisering van die soteriologiese uitsprake bestudeer word. Hierdie bestudering lewer drie beeldgroepe van soteriologiese metafore op, naamlik:

- redding as deel wees van 'n huisgesin, met God as Vader;

- redding as die teruggebring van verdwaalde skape na Christus, hulle herder;

- redding as genees wees deur Christus se wond. 
Die aard van twee verdere beeldgroepe lyk op die oog af ook soteriologies, maar deeglike oorweging wys dat hulle nie as soteriologies beskou kan word nie, naamlik die beeldgroep van dié wat gered is as (tempel)gebou met Christus as hoekklip (1 Pet. 2:4$9)^{20}$ en die beeldgroep van die wat gered is as erfgename (1 Pet. $1: 3 ; 3: 7){ }^{21}$

Die verskillende soteriologiese metafore kan vervolgens in die drie beeldgroepe gekategoriseer en geïnterpreteer word. Hierdie interpretasie het vir die doeleindes van hierdie artikel net een doelwit: om vas te stel wat die $a b$ quo en die ad quem van elkeen van die geïdentifiseerde soteriologiese metafore is.

20 Die beeldgroep van dié wat gered is as (tempel)gebou met Christus as hoekklip (1 Pet. 2:4-9) fokus op die tempelgebou (2:5: ốkOS) wat Christus as lewende klip

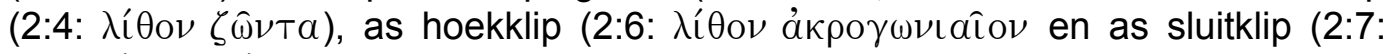
$\kappa \in \phi a \lambda \eta े \nu \gamma(\omega \nu$ ías) sien. Die lesers is die lewende klippe van hierdie geestelike

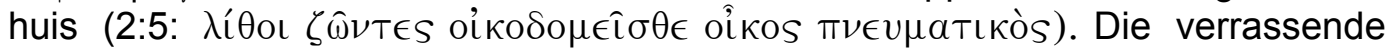
elemente van hierdie beeldgroep is die volgende: (1) Die klippe is "lewend" sowel Christus as hoekklip en sluitklip, as die gelowiges as bouklippe; (2) die huis is nie 'n gewone huis nie, maar 'n "geestelike huis"; (3) hierdie tempel hét nie 'n priesterdom nie, maar ís self 'n priesterdom. Die ab quo en die ad quem waarop hierdie beeldgroep dui, is dat die volk vroeër sonder tempel en priesters was. Nou het hulle baie meer ontvang: hulle wórd self die tempel van God, terwyl hulle hulle taak as koninklike priesterdom vervul. Die lesers word dus nie opgeroep om na die Lewende Klip te kom om gered te word nie (in welke geval hierdie beeld wel soteriologies sou wees). Hulle is reeds lewende klippe, juis vanweë hulle verhouding met die Lewende Klip! Hierdie perikoop oorreed dus dié wat reeds gered is om hulle gemeenskaplike verantwoordelikheid om "geestelike offers te bring wat vir God aanneemlik is" (2:5) ter harte te neem en om 'n "koninklike priesterdom te wees" (2:9).

21 Die beeldgroep van dié wat gered is as erfgename wat met die oog op hulle

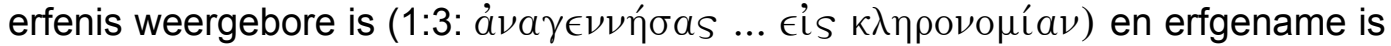

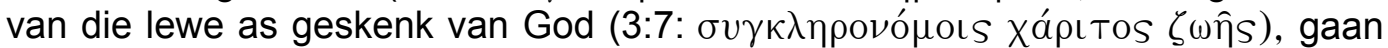
nie oor die oorgang van 'n toestand van verlore wees na 'n toestand van gered wees nie, maar spel uit wat die gevolg is van hulle redding: die feit dat hulle gevolglik erfgename is. 


\subsection{Redding as deel wees van 'n gesin, met God as Vader 22}

\subsubsection{Redding as wéér gebore deur God ${ }^{23}$}

\begin{tabular}{|c|c|}
\hline 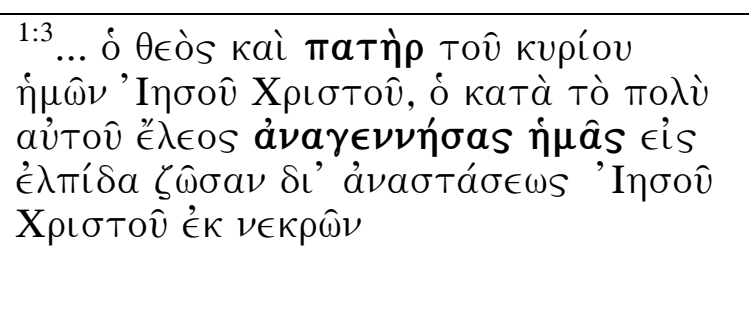 & $\begin{array}{l}{ }^{1: 3} \text { Aan God, die Vader van ons Here } \\
\text { Jesus Christus, kom al die lof toe! }{ }^{24} \text { In } \\
\text { sy groot ontferming het Hy ons } \\
\text { weergebore laat word }{ }^{25} \text { deur die } \\
\text { opstanding van Jesus Christus tussen } \\
\text { die dooies uit. }\end{array}$ \\
\hline 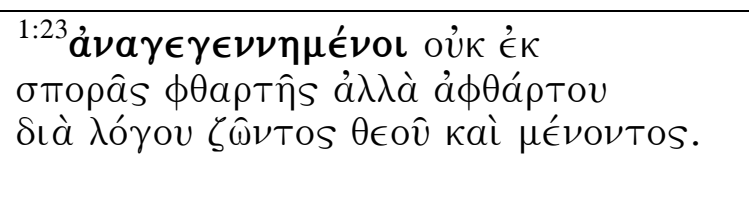 & $\begin{array}{l}\text { 1:23 Julle is immers weergebore, nie uit } \\
\text { verganklike saad nie, maar uit } \\
\text { onverganklike saad: die lewende en } \\
\text { blywende woord van God. }\end{array}$ \\
\hline 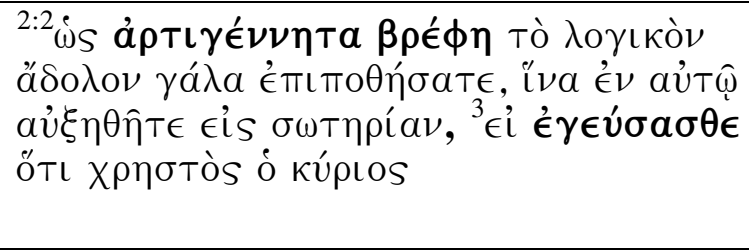 & $\begin{array}{l}\text { 1:2 Julle moet soos pasgebore babatjies } \\
\text { smag na die suiwer geestelike melk, } \\
\text { sodat julle daardeur kan opgroei in julle } \\
\text { redding. } 26 \text { Julle het immers geproe } 27 \\
\text { dat die Here goed is. }\end{array}$ \\
\hline
\end{tabular}

22 Vergelyk Van der Watt (2000:400-406) vir 'n bespreking van die metaforiese ontwikkeling van die gesin-beeldgroep.

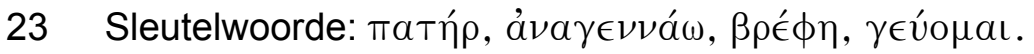

24 Die 1983-Afrikaanse Vertaling word telkens gebruik, behalwe waar dit noodsaaklik geag word om daarvan af te wyk. Waar sodanige afwyking 'n soteriologiese metafoor raak, word die 1983-Vertaling van die betrokke frase in 'n voetnoot gegee, en die afwyking word kortliks gemotiveer.

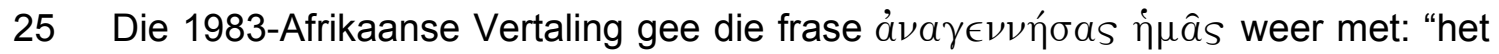
Hy ons die nuwe lewe geskenk". Hierdie vertaling verskuil die beeld wat met

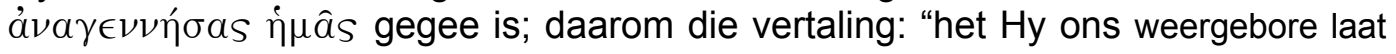
word".

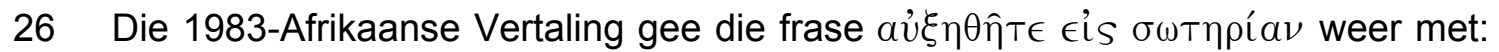
"opgroei en die saligheid verkry". Hierdie vertaling laat dit klink asof die verkryging van die redding afhanklik is van die "opgroei". Die vertaling "opgroei in julle redding" vermy hierdie probleem.

27 Die 1983-Afrikaanse Vertaling gee die woord $\epsilon^{\prime} \gamma \in \dot{\epsilon} \sigma a \sigma \theta \epsilon$ weer met: "julle het ondervind". Hierdie vertaling verskuil die beeld wat met '́\} $\epsilon^{\prime} \sigma \alpha \sigma \theta \epsilon$ gegee is (naamlik dat dit gaan oor 'n babatjie wat moedersmelk drink); daarom die vertaling: "julle het geproe". 
Hierdie beeldgroep fokus op 'n pa wat (weer) geboorte gee (1:3:

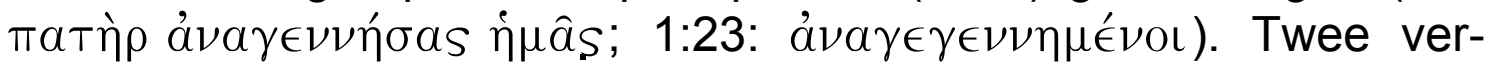
rassende elemente is deur die beeld bewerk: dit is 'n pa (en nie 'n ma28 nie) wat "geboorte gee", en dit word beklemtoon dat dit nie 'n natuurlike geboorte is nie, maar 'n "oor"-geboorte; hulle is "wéér"gebore. Die metafoor word in 2:2 verder ontwikkel: soos dit wat ná 'n natuurlike geboorte gebeur, is die weergeborenes pasgebore

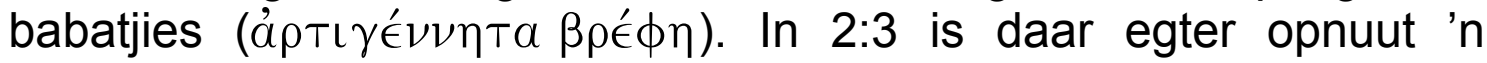
verrassende element: die pasgebore babatjies kry colostrum (die eerste moedersmelk ná geboorte) wat hulle proe ('́\} $\gamma \in \dot{v} \sigma \alpha \sigma \theta \epsilon)$; hulle kry dit egter van 'n pá!

Dit is nou moontlik om 'n gevolgtrekking te maak oor die ab quo en die ad quem waarop hierdie beeldgroep dui (redding as weergebore wees deur die Vader, en as die proe van die colostrum wat die Vader gee):

- Voordat die eerste lesers/hoorders van 1 Petrus Christene geword het, was hulle as uitlanders grootliks enkelinge, dood in sonde. Nou is hulle ingetrek in God se groot gesin, omdat God hulle pa geword het deur aan hulle geboorte te gee.

- Onmiddellik ná geboorte (eintlik as deel van die geboorteproses) ontvang die pasgebore babatjies colostrum. Hierdie beeld dui nog verder op God se onverdiende goedheid: Hy maak hulle sy kinders net om één rede - omdat Hý wil. Twee dinge gebeur met die pasgebore babatjies: hulle proe die goedheid van God se "eerste" melk (die colostrum) en dit wakker hulle aptyt aan vir nóg melk. Dit alles werk daartoe mee dat die pasgebore babatjie uiteindelik groei en 'n kragtige volwassene word. Sonder die melk sou die babatjie 'n pap babatjie gebly het.

28 Barkhuizen (2002:57) is oortuig dat die moeder-element in die beeld van die nuwe geboorte vervang is met die opstanding van Jesus Christus uit die dood. Hiervolgens word Jesus se opstanding uit die dood as die regenererende aspek van die nuwe lewe beskou. 


\subsubsection{Redding as deur God ingekoop in sy huishouding ${ }^{29}$}

\begin{tabular}{|c|c|}
\hline 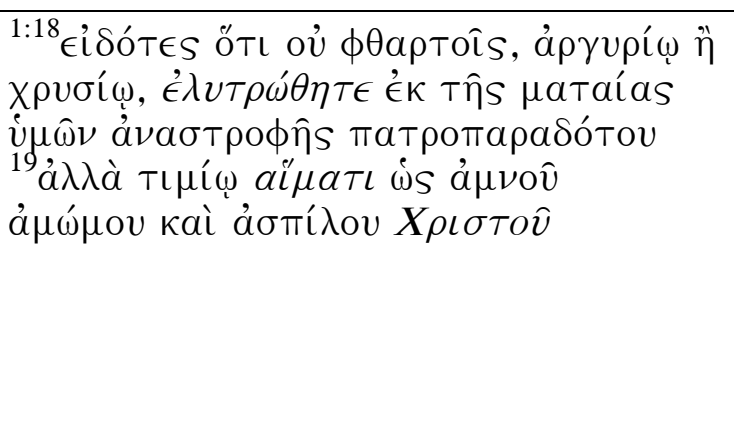 & $\begin{array}{l}\text { 1:18 Julle weet tog dat julle nie met } \\
\text { verganklike dinge soos silwer of goud } \\
\text { losgekoop is uit julle sinlose bestaan } \\
\text { wat julle van julle voorouers oorgeërf } \\
\text { het nie. }{ }^{19} \text { Inteendeel, julle is los- } \\
\text { gekoop met die kosbare bloed van } \\
\text { Christus, soos dié van 'n lam }{ }^{30} \text { wat } \\
\text { vlekloos en sonder liggaamsgebrek } \\
\text { is. }\end{array}$ \\
\hline 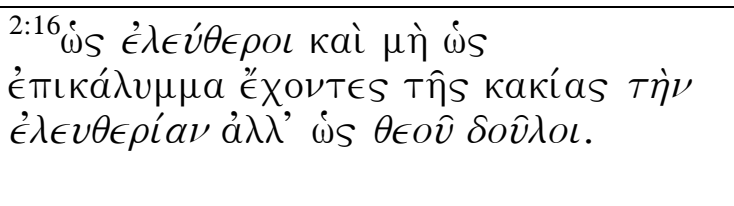 & $\begin{array}{l}2: 16 \text { Julle is mos vry, maar moenie julle } \\
\text { vryheid gebruik as dekmantel om } \\
\text { kwaad te doen nie. Gebruik dit om } \\
\text { slawe van God te wees. } \mathbf{3 1}\end{array}$ \\
\hline 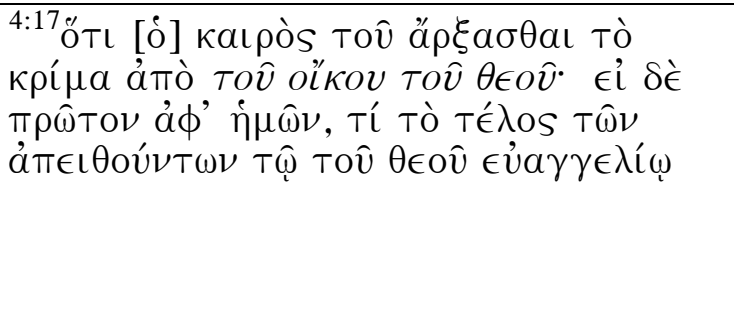 & $\begin{array}{l}\text { 4:17 Die tyd vir die oordeel het aan- } \\
\text { gebreek; dit begin by die huis van } \\
\text { God. En as ook ons geoordeel word, } \\
\text { en dit is nog maar die begin, wat sal } \\
\text { die uiteinde dan wees van hulle wat } \\
\text { nie na die evangelie van God wou } \\
\text { luister nie? }\end{array}$ \\
\hline
\end{tabular}

Hierdie beeldgroep gebruik die verskynsel dat slawe destyds gekoop is (1:18: ' $\epsilon^{\lambda} \nu \tau \rho(\hat{\theta} \theta \eta \tau \epsilon)$ en sodoende die eiendom van hulle nuwe eienaar (2:16: $\theta \in \mathrm{\epsilon} \hat{v} \delta o \hat{v} \lambda o \mathrm{l})$ in sy huishouding (4:17:

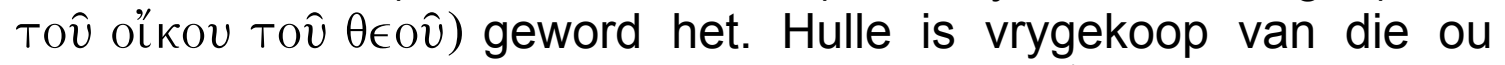

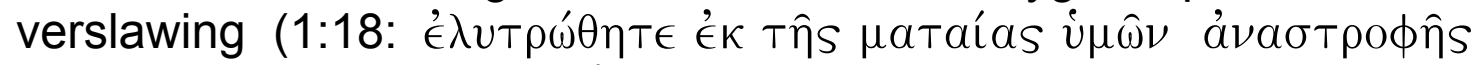

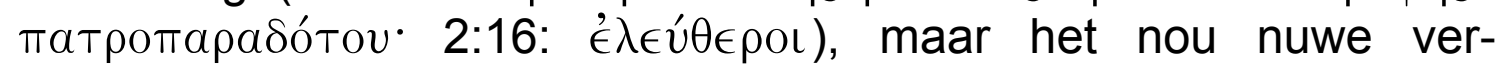
pligtings teenoor hulle nuwe eienaar (2:16: $\theta \in \mathrm{v} \hat{\delta} \delta o \hat{v} \lambda \circ \mathrm{l})$. Die verrassende elemente van hierdie beeldgroep is geleë in die volgende:

- Hulle is gekoop - nie met silwer of goud nie, maar met die kosbare bloed van Christus.

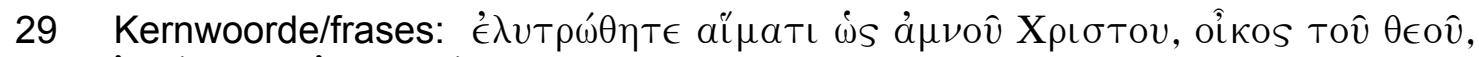

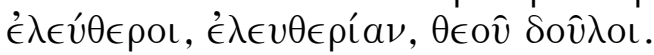

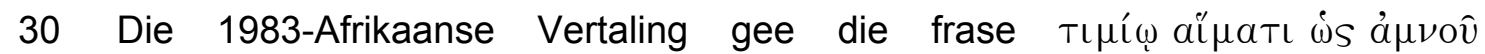

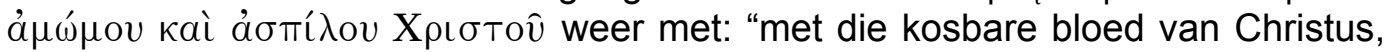
die Lam wat vlekloos en sonder liggaamsgebrek is". Met hierdie vertaling word die $@$ in die Grieks geïgnoreer; daarom dus die vertaling: "met die kosbare bloed van Christus, soos dié van "n lam wat vlekloos en sonder liggaamsgebrek is".

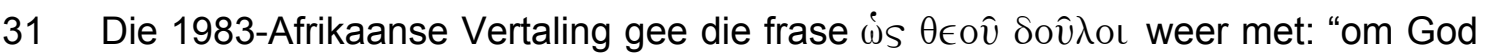
te dien". Dié vertaling verskuil die beeld wat met $\theta \epsilon 0 \hat{v} \delta o \hat{\lambda}$ or gegee is; daarom dus die vertaling: "om slawe van God te wees". 
- Hulle is vrygekoop - nie van 'n vorige eienaar nie, maar uit 'n sinlose bestaan wat hulle van hulle voorouers oorgeërf het.

- Alhoewel hulle nou bevryde mense geword het, lê daar op hulle die verpligting om hulle aan God as hulle nuwe eienaar te onderwerp.

Dit is nou moontlik om 'n gevolgtrekking te maak oor die ab quo en die ad quem waarop hierdie beeldgroep dui (redding gesien as die deur God in sy huishouding ingekoop met die kosbare bloed van Christus as betaalmiddel):

- Die gelowiges was voorheen as slawe die eiendom van een of ander magtige persoon, wat nie in die metafoor genoem word nie. God het hulle egter vrygekoop en nou is hulle vry!

- Die gelowiges was ver-slaaf aan 'n sinlose bestaan wat hulle van hulle voorouers oorgeërf het, maar God het hulle sý slawe gemaak, deurdat Hy hulle gekoop het!

- Hulle was niks werd nie en niemand sou iets vir hulle wou betaal nie. Vir God is hulle egter só kosbaar, dat Hy 'n dúúr prys vir hulle betaal: die kosbare bloed van Christus.

- Hulle was dakloos; nou het God hulle in sý huis ingebring en hulle deel van sý huishouding gemaak! 


\subsubsection{Redding as omvorm tot die volk van God32}

\begin{tabular}{|c|c|}
\hline 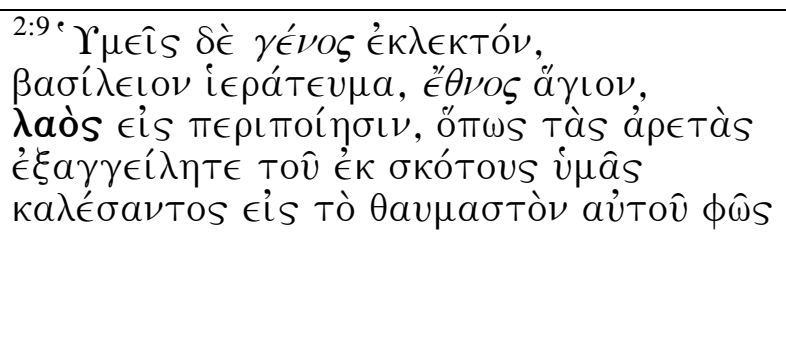 & $\begin{array}{l}\text { 2:9 Julle, daarenteen, is 'n uitverkore } \\
\text { volk, 'n koninklike priesterdom, 'n } \\
\text { nasie wat aan God toegewy is, 'n } \\
\text { volk wat God s'n is, om die magtige } \\
\text { dade te verkondig van Hom wat julle } \\
\text { uit die duisternis geroep het na sy } \\
\text { wonderbare lig. }\end{array}$ \\
\hline 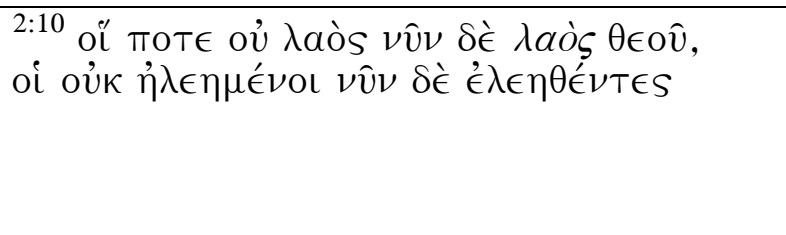 & $\begin{array}{l}\text { 2:10 Julle was vroeër geen volk nie, } \\
\text { maar nou is julle die volk van God. } \\
\text { Daar is toe geen onverdiende liefde } \\
\text { aan julle bewys nie, maar nou is } \\
\text { onverdiende liefde aan julle bewys. }\end{array}$ \\
\hline
\end{tabular}

Hierdie beeldgroep fokus op die verskynsel dat 'n koning 'n volk tot

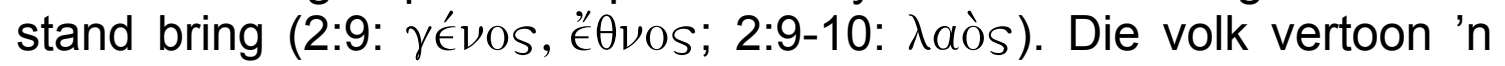
eenheid en 'n hoë graad van integrasie - 'n gegewe wat aan die lede van daardie volk sekuriteit gee en die gevoel dat hulle tuisgekom het. Die verrassende elemente van hierdie beeldgroep is geleë in die volgende:

- Individue wat nie bloedverwante is nie, word 'n volk, 'n yévos;

- hulle volkswording is nie iets wat hulle self bedink het nie, maar

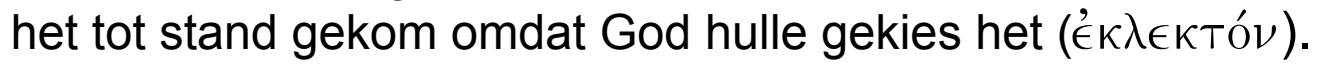

Dit is nou moontlik om 'n gevolgtrekking te maak oor die ab quo en die ad quem waarop hierdie beeldgroep (redding as omvorm tot die volk van God) dui:

Die gelowiges was uitlanders en bywoners, verstrooide individue sonder enige sekuriteit, sonder 'n gevoel van om êrens te behoort en sonder om tot ' $n$ volk geïntegreer te wees. Nou het hulle egter nie net God se gesin en deel van sy huishouding geword het nie, hulle het ook 'n volk geword. Hierdie volk is egter nie maar net een volk van baie nie: hulle is die uitverkore volk, 'n nasie wat aan God toegewy is, 'n volk wat God s'n is!

32 Sleutelwoorde: $\gamma$ '́vos, $e^{\prime} \theta \nu o s, \lambda a o ̀ s$. 


\subsection{Redding as die teruggebring van verdwaalde skape na Christus, hulle herder ${ }^{33}$}

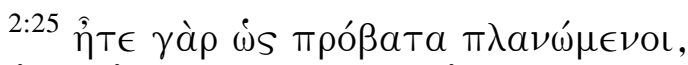

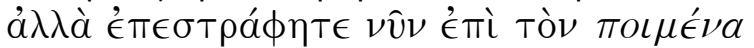

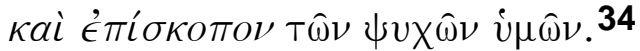

2:25 Julle het immers soos skape rondgedwaal, maar nou is julle teruggebring 35 na julle Herder en die Bewaker van julle lewe.

Hierdie beeld fokus op die verskynsel dat skape afdwaal (2:25:

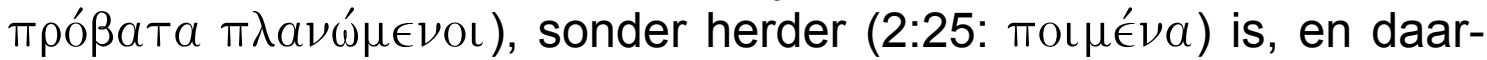
om in groot gevaar verkeer. Die verrassende elemente van hierdie beeldgroep is geleë die volgende:

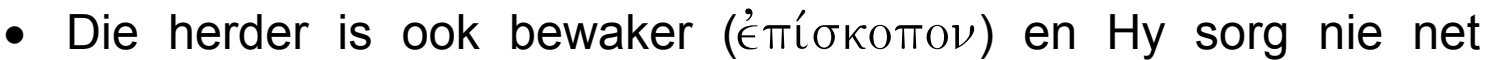
liggaamlik vir die skape nie, maar bewaak ook hulle lewe.

- Dit is nie die skape wat die inisiatief neem om die herder op te soek nie, maar dit is die Herder wat hulle terugbring.

Dit is nou moontlik om 'n gevolgtrekking te maak oor die ab quo en die ad quem waarop hierdie beeldgroep dui (redding as die teruggebring van verdwaalde skape na Christus hulle herder):

- Hulle was verdwaal en sonder iemand wat hulle oppas; nou is hulle onder die liefdevolle sorg van Christus, omdat hulle teruggebring is na hulle Herder.

- Hulle was verdwaal en nou - sonder enige inisiatief van hulle kant - is hulle teruggebring na die Herder en Bewaker van hulle lewe.

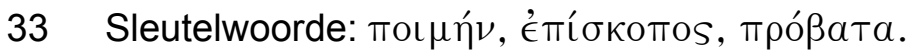

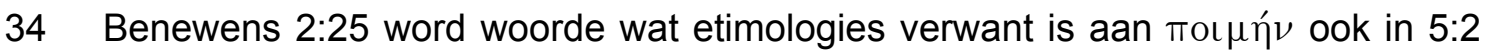

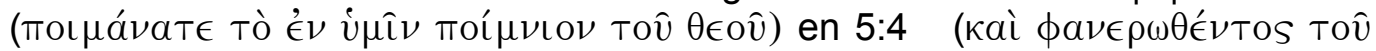

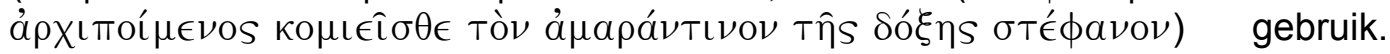
Hierdie gebruik is egter nie primêr soteriologies nie.

35 Die 1983-Afrikaanse Vertaling gee die woord $\epsilon \pi \epsilon \sigma \tau \rho a ́ \phi \eta \tau \epsilon$ weer met: "julle het teruggekom". Hierdie vertaling verloor egter uit die oog dat $\epsilon \pi \epsilon \sigma \tau \rho a ́ \phi \eta T \epsilon$ passief is en dus kan aandui dat die inisiatief vir die terugkeer nie by die skape lê nie, maar by God - daarom die vertaling: "is julle teruggebring". 


\subsection{Redding as genees deur Christus se wond ${ }^{36}$}

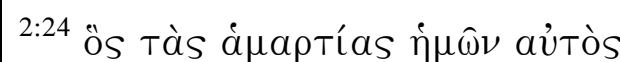
à $\nu$ ท́

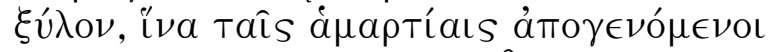

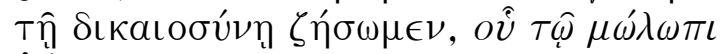
¿á $\theta \eta \tau \epsilon$.
${ }^{24} \mathrm{Hy}$ het self ons sondes in sy liggaam aan die kruis gedra. Daardeur is ons vir die sondes dood en kan ons lewe omdat God ons verhouding met Hom herstel het. Deur sy wond $\mathbf{3 7}$ is julle genees.

Hierdie metafoor fokus op redding as 'n genesing (2:24: iá $\theta \eta T \epsilon)$. Die verrassende element van hierdie metafoor is dat die genesingsproses nie bewerkstellig word deur medisyne van een of ander soort nie, maar deur "die wond van Christus" (2:24: oî $T \hat{\varphi} \mu(\hat{\omega} \lambda \omega \pi \iota)$. Hierdie metafoor sluit direk aan by die vorige stelling dat Christus "self ons sondes in sy liggaam aan die kruis gedra" het en "ons kan lewe" (2:24a).

Dit is nou moontlik om 'n gevolgtrekking te maak oor die ab quo en die ad quem waarop hierdie beeld dui (redding as genees wees deur Christus se wond):

- Hulle was dodelik gewond en eintlik sterwend; nou is hulle gesond, aangesien hulle genees is en hulle die gesondheid en krag het om te leef soos God dit wil hê!

\section{Gevolgtrekking}

Dit is duidelik dat in 1 Petrus, vanuit 'n metaforiese hoek bekyk, die soteriologie hoofsaaklik met behulp van die gesin-beeldgroep ontwikkel word. Die soteriologie word nie as 'n stilstaande gebeure beskryf nie, maar as 'n kompleks van relasies en gebeure. God se reddende handeling word voorgestel as 'n pa wat geboorte gee en direk na geboorte - feitlik as deel van die geboorteproses - voed hy die pasgebore babatjie colostrum. Binne hierdie selfde beeldgroep word die reddingsgebeure ook voorgestel as 'n patria potestas wat dié wat gered is, inkoop (asof dit slawe is wat vrygekoop word). Dié wat gered is, word ingekoop om deel van sy huishouding te wees; die betaalmiddel wat Hy gebruik, is die kosbare bloed van Christus.

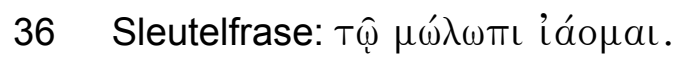

37 Die 1983-Afrikaanse Vertaling gee weer met "wonde". Die woord is in die enkelvoud, en daarom word dit met "wond" weergegee. 
Die finale element van hierdie gesin-beeldgroep is dié van ' $n$ koning wat dié wat gered is, omvorm tot 'n volk.

Twee verdere (al is dit sekondêre) beeldgroepe word egter ook gebruik: Redding as die terugbring van verdwaalde skape na Christus hulle herder, en redding as genees wees deur Christus se wond.

Die $a b$ quo en die ad quem waarop elkeen van hierdie beeldgroepe dui, kan soos volg saamgevat word:

\section{Redding as deel wees van 'n gesin, met God as Vader}

- Voordat die eerste lesers/hoorders van 1 Petrus Christene geword het, was hulle onverbonde individue, dood in sonde. Nou is hulle deel van 'n groot gesin, omdat God hulle pa geword het deur aan hulle geboorte te gee.

- Onmiddellik ná geboorte (eintlik as deel van die geboorteproses) ontvang die pasgebore babatjies colostrum. Hierdie aksie dui nog verder op God se onverdiende goedheid: Hy maak hulle sy kinders net om één rede - omdat Hý wil. Twee dinge gebeur met die pasgebore babatjies: hulle proe die goedheid van God se "eerste" melk (die colostrum) en dit wakker hulle aptyt aan vir nóg melk. Dit alles dra daartoe by dat die pasgebore babatjie uiteindelik groei en 'n kragtige volwassene word. Sonder die melk sou die babatjie 'n pap babatjie gebly het.

- Die gelowiges was voorheen as slawe die eiendom van een of ander magtige persoon, wat nie in die metafoor genoem word nie. God het hulle egter gekoop en nou is hulle vry!

- Hulle was ver-slaaf aan 'n sinlose bestaan wat hulle van hulle voorouers oorgeërf het, maar God het hulle sý slawe gemaak, deurdat Hy hulle gekoop het.

- Hulle was niks werd nie en niemand sou iets vir hulle wou betaal nie. Vir God is hulle egter só kosbaar dat Hy 'n dúúr prys vir hulle betaal: die kosbare bloed van Christus.

- Hulle was dakloos; nou het God hulle in sý huis ingebring en hulle deel van sý huishouding gemaak.

- Die gelowiges was uitlanders en bywoners, verstrooide individue sonder enige sekuriteit, sonder 'n gevoel van om êrens te behoort en sonder om in 'n volk geïntegreer te wees. Nou het hulle egter nie net God se gesin en deel van sy huishouding geword nie; hulle het ook 'n volk geword. Hulle is egter nie maar net een volk 
van baie nie: hulle is die uitverkore volk, 'n nasie wat aan God toegewy is, 'n volk wat God s'n is.

\section{Redding as die terugbring van verdwaalde skape na Christus, hulle herder}

- Hulle was verdwaal en sonder iemand wat hulle oppas; nou is hulle onder die liefdevolle sorg van Christus, omdat hulle teruggebring is na hulle Herder.

- Hulle was verdwaal en nou - sonder enige inisiatief van hulle kant - is hulle teruggebring na die Herder en Bewaker van hulle lewe.

\section{Redding as genees deur Christus se wond}

- Die gelowiges was dodelik gewond en eintlik sterwend; nou is hulle gesond aangesien hulle genees is. Ook het hulle nou die gesondheid en krag om te leef soos God dit wil hê!

Hierdie matriks van soteriologiese metafore (tesame met die voorlopige interpretasie van die metafore) kan nou gebruik word in die verdere beskrywing van die soteriologie in 1 Petrus.

\section{Geraadpleegde bronne}

ARISTOTLE. 1899. Peri Poiêtikês. (In Moore, E., ed. Aristotelis de arte poetica [Vahlen's text]. Oxford: James Parker.)

BARKHUIZEN, J.H. 2002. Die eulogie in 1 Petrus 1:3-12. In die Skriflig, 36(1):45-66.

CAIRD, G.B. 1980. The language and imagery of the Bible. Philadelphia: Westminster.

DAGUT, M.B. 1971. A linguistic analysis of some semantic problems of Hebrew-English translation. Jerusalem: Hebrew University of Jerusalem.

DE VILLIERS, J.L. 1993. 1 Peter. (In Du Toit, A.B., ed. Guide to the New Testament. Volume VI: The gospel of John; Hebrews to Revelation: Introduction and theology. Halfway House: NG Kerkboekhandel. p.143170.)

DE WAARD, J. 1974. Biblical metaphors and their translation. The Bible Translator, 25:107-116.

GARRETT, S.R. 1992. Sociology of early Christianity: The Anchor Bible Dictionary. Vol. 6. New York: Doubleday. p. 89-99.)

GUNTON, C.E. 1989. The actuality of atonement: A study of metaphor, rationality and the Christian tradition. Grand Rapids: Eerdmans.

KAISER, W.C. \& SILVA, M. 1994. An introduction to Biblical hermeneutics. Grand Rapids: Zondervan.

LONGMAN, T. III. 1987. Literary approaches to biblical interpretation. Grand Rapids: Academic Books.

MARROW, S.B. 1990. Principles for interpreting the New Testament soteriological terms. New Testament Studies, 36:268-280. 
MARTIN, T.W. 1992. Metaphor and composition in 1 Peter. Atlanta: Scholars Press.

MICHAELS, J.R. 1988. 1 Peter. Waco: Word Books.

MILLER, D.M. 1971. The net of Hephaestus: A study of modern criticism and metaphysical metaphor. The Hague: Mouton.

MOUTON, E. 2002. Reading a New Testament document ethically. Leiden: Brill.

NIDA, E.A. \& TABER, C.R. 1974. The theory and practice of translation. Leiden: Brill.

THISELTON, A.C. 1977. Semantics and New Testament interpretation. (In Marshal, I.H., ed. New Testament interpretation: Essays in principles and methods. Exeter: The Paternoster Press. p. 75-105.)

VAN DER WATT, J.G. 2000. Family of the King: Dynamics of metaphor in the Gospel according to John. Leiden: Brill.

VAN RENSBURG, Fika J. 1992. The outline of 1 Peter: A reconsideration. Ekklesiastikos Pharos, 74(1):26-41.

VAN RENSBURG, Fika J. 2000. Dekor of konteks? Die verdiskontering van sosiohistoriese gegewens in die interpretasie vir die prediking en pastoraat van ' $n$ Nuwe-Testamentteks, geïllustreer aan die hand van die 1 Petrusbrief. Skrif en Kerk, 564-582.

VAN UNNIK, W.C. 1980. Corpus Hellenisticum Novi Testamenti. (In Barrett, C.K., ed. Sparsa collecta: The collected essays of W.C. van Unnik .Part 2. Leiden: Brill. p.194-214.)

WEINRICH, H. 1976. Sprache in Texten. Stuttgart: Klett.

\section{Kernbegrippe:}

1 Petrus: argument van

metafoor

sosiohistoriese ekologie

soteriologie

\section{Key words:}

1 Peter: argument of

metaphor

sociohistoric ecology

soteriology 
